\title{
Periorbital lupus erythematosus profundus: A case report and review of the literature
}

Periorbital lupus eritematozus profundus: Bir olgu sunumu ve literatürün gözden geçirilmesi

\section{Didem Mullaaziz, ๑ Serap Maden, ๑ Orgun Deren*, ๑ Hanife Özkayalar**}

Near East University Faculty of Medicine, Department of Dermatology and Venereology; *Department of Plastic and Reconstructive Surgery;

**Department of Pathology, Nicosia, Cyprus

\begin{abstract}
Lupus erythematosus profundus (LEP), is a rare form of, chronic cutaneous LE, also called lupus erythematosus panniculitis. LEP is characterized by subcutaneous fatty tissue involvement spesifically in patients with LE. Before systemic LE was diagnosed, very few reports reported the presence of lesions of lupus erythematosus profundus. The rare manifestations of the disease are remarkable with the unusual features of the cases. A 43-year-old female patient diagnosed with bilateral periorbital LEP was presented and the literature was reviewed. Significant clinical improvement was achieved in the patient who was given systemic hydroxychloroquine and topical pimecrolimus therapy. This report suggests that asymptomatic periorbital erythema and edema may develop as a manifestation of LEP.

Keywords: Lupus erythematosus, lupus erythematosus profundus, lupus panniculitis, orbital area
\end{abstract}

\section{Öz}

Lupus eritematozus profundus (LEP), nadir görülen bir kronik kutanöz lupus eritematozus türü olup, lupus eritematozus panniküliti olarak da adlandırımaktadır. LEP, LE hastalarında spesifik olarak subkutan yağ doku tutulumu ile karakterizedir. Sistemik lupus eritematozus tanısı konulmadan önce LEP lezyonlarının varlı̆̆ını bildiren çok az sayıda rapor bildirilmiştir. Hastalığın nadir görülen bulguları, olguların sıra dışı özellikleri ile dikkat çekici olmaktadır. Burada bilateral periorbital LEP tanısı konulan, 43 yaşında bir kadın olgu sunulmuş ve literatür gözden geçirilmiştir. Sistemik hidroksiklorokin ve topikal pimekrolimus tedavisi verilen hastada anlamlı klinik iyileşme sağlanmıştır. Bu rapor, asemptomatik periorbital eritem ve ödemin LEP'nin bir bulgusu olarak gelişebileceğini desteklemektedir.

Anahtar Kelimeler: Lupus eritematozus, lupus eritematozus profundus, lupus panniküliti, orbital alan

\section{Introduction}

Lupus erythematosus profundus (LEP) is a cutaneous variant of lupus erythematosus (LE), principally characterized by involvement of the deep dermis and subcutaneous cellular tissue. Approximately $2-7 \%$ of patients diagnosed with systemic lupus erythematosus (SLE) develop lupus panniculitis ${ }^{1}$. LEP is usually seen in the female population in the third-to-sixth decades of life. Cutaneous manifestations include indurated plaques, subcutaneous nodules, ulcerations and toughened subcutaneous plaques, which are healed with atrophy and residual scarring. The lesions occur predominantly on the face, particularly the forehead and cheeks, as well as the upper arms, upper trunk, breasts, buttocks, and thighs. The lesions may appear individually or in association with manifestations of discoid lupus erythematosus (DLE) or SLE². In SLE patients, it is relatively easy to perform LEP diagnosis.

Address for Correspondence/Yazışma Adresi: Didem Mullaaziz MD, Near East University Faculty of Medicine, Department of Dermatology and Venereology, Nicosia, Cyprus

Phone: +90 5488290819 E-mail: didem_mullaaziz@yahoo.com Received/Geliş Tarihi: 19.06.2019 Accepted/Kabul Tarihi: 28.04.2020 ORCID: orcid.org/0000-0001-6615-1483

(C) Copyright 2020 by Turkish Society of Dermatology and Venereology

Turkderm - Turkish Archives of Dermatology and Venereology published by Galenos Yayınevi. 
Nevertheless, subcutaneous nodules without any symptoms need to be defined in a histological method. Herein, we report a female LEP case with isolated periorbital area involvement, which is the first case of its kind reported in the literature to the best of our knowledge.

\section{Case Report}

A 43-year-old woman referred to our department with redness and swelling around her eyes that started 6 months previously. The patient had no complaints of pain, itching or burning. Dermatological examination of the patient revealed violaceous erythematous plaques with edema on the bilateral periorbital area, which were more prominent on the left side. Moreover, the lesions were indurated in the malar area (Figure 1A, B).

A skin biopsy with subcutaneous fat tissue was taken from the left lower eyelid by plastic surgery in order to provide less scarring. Histological examination demonstrated lymphocytic panniculitis, hyaline degeneration of the fat with mucin deposition and basement membrane degeneration (Figure 2-4).

The remaining physical examination was observed to be normal. Questioning of SLE criteria was observed to be negative. The patient did not describe photosensitivity, muscle pain or arthralgia. There were no signs of malar rash, discoid rash, alopecia, Gottron papules, Gottron sign, periungual telangiectasias, poikiloderma on the " $\mathrm{V}$ " of the anterior chest, oral ulcers, or arthritis. Routine blood examination results including complete blood cell count, liver and kidney function tests, erythrocyte sedimentation rate and C-reactive protein were

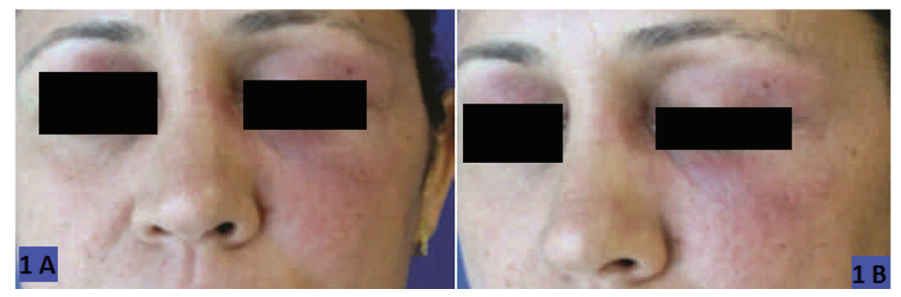

Figure 1. A, B) Violaceous erythematous plaques with edema on bilateral periorbital area



Figure 2. Dense lymphocytic infiltration in subcutaneous region (hematoxylin and eosin, x20) within normal limits. Antinuclear antibody (ANA) and extractable nuclear antigen antibodies panel were negative. Serum complement levels and rheumatoid factor were normal. In urine analyses, there was no proteinuria. The levels of classic muscle enzymes including creatine kinase (CK), aldolase, glutamic oxaloacetic transaminase (GOT), alanine transaminase (ALT) and lactate dehydrogenase (LDH) were normal. She had no muscular weakness in physical examination. Ophthalmological examination and orbital magnetic resonance imaging were normal. These clinical, laboratory and histopathological findings were compatible with the diagnosis of periorbital LEP. After the visual field examination was reported to be normal by ophthalmology. We recommended hydroxychloroquine $200 \mathrm{mg} /$ day and topical pimecrolimus. She was followed-up and photos were documented every two weeks. Two months after the treatment, there was a significant improvement compared to the pre-treatment. At the end of the sixth month, it was observed that complete regression of the erythema and edema had occurred and the lesions were flattened (Figure 5A, B). Informed consent was obtained from the patient for publication of this case report.

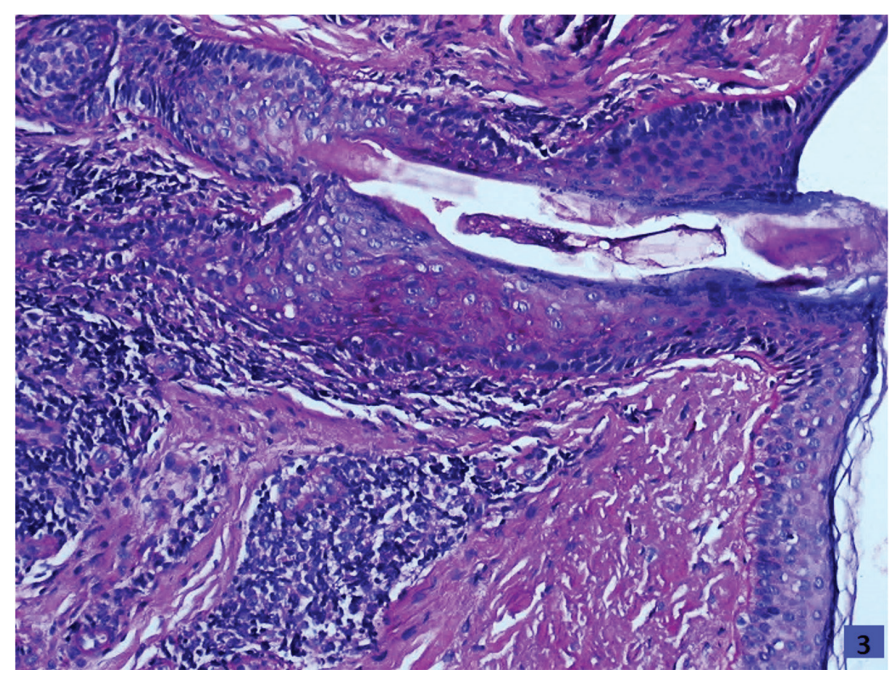

Figure 3. Basal membrane was destroyed (PAS, x20)

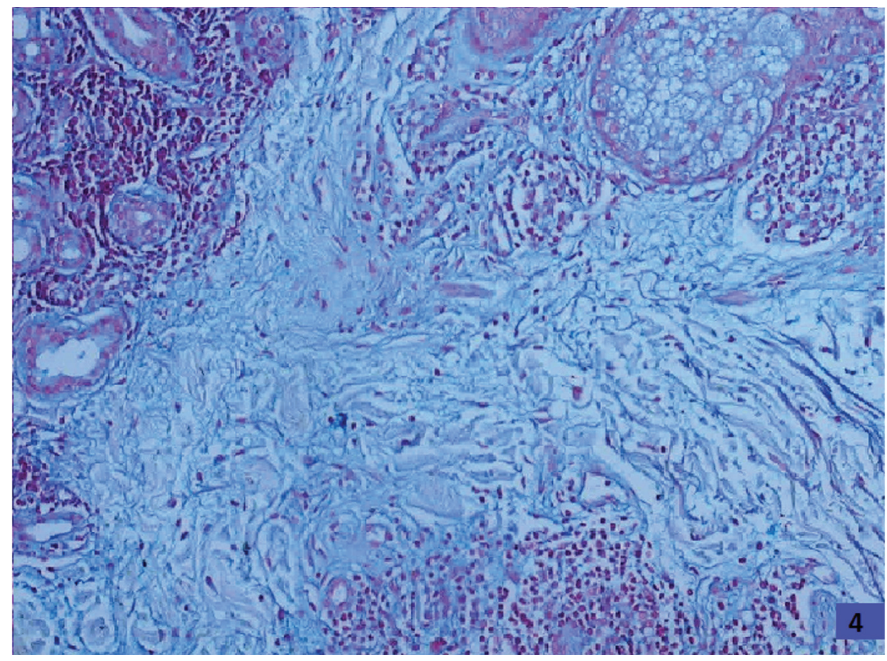

Figure 4. Mucin accumulation in dermis (mucicarmine, x20) 


\section{Discussion}

LEP is an inflammatory disease involving the deep dermis and subcutaneous cellular tissue, which may occur individually or prior to SLE/DLE 1 . It was first described by Kaposi in 1883 and subsequently defined as LEP by Irgang in $1940^{3}$.

LEP is more common in women and has a female to male ratio of 4.5:1. The age of onset ranges from 20 to 60 years, and the mean age is 36 years ${ }^{4}$. Consistent with the literature, our case involved a middle-aged woman. Cutaneous manifestations were predominantly subcutaneous nodules and hardened plaques appearing on the forehead, cheeks, proximal limps, upper trunk, buttocks, which were fat-rich tissues ${ }^{1,2}$.

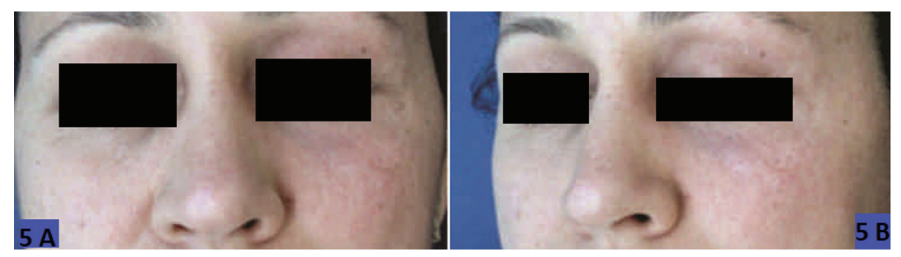

Figure 5. A, B) Complete regression of erythema and edema after 6 months of treatment
Arai and Katsuoka ${ }^{4}$ demonstrated that the most common site was the face in their study conducted on 44 patients with LEP3. In our case, lesions were also observed on the face with an erythematous edematous plaque. Subcutaneous nodules and plaques are often adhered to the overlying skin with atrophy and residual scarring, which are healed after a long period of time ${ }^{1,5}$. Atrophy or scarring was not observed in the treatment area during the follow-up of our patient.

The presence of periorbital edema and erythema suggested heliotrope erythema and led us to consider dermatomyositis in differential diagnosis. She had no muscular weakness and levels of the classic muscle enzymes including CK, aldolase, GOT, ALT and LDH were normal. Additionally, Gottron papules Gottron sign, periungual telangiectasia and poikiloderma involving the " $\mathrm{V}$ " of the anterior chest findings were not detected.

Periorbital edema and erythema could be symptoms of LEP and should be considered in the differential diagnosis, despite being rare. The initial manifestation of the eyelid edema of SLE incidence is $0.1 \%$, and its overall incidence is $4.8 \%$. It is thought that periorbital panniculitis might have been ignored in the past, meaning that a deep skin biopsy from these areas was not taken and the histologic findings in LEP might have been interpreted as DLE ${ }^{6}$. We searched

\begin{tabular}{|c|c|c|c|c|c|}
\hline Reference & $\begin{array}{l}\text { Age, } \\
\text { sex }\end{array}$ & Initial symptom & Other findings & Lab & Treatment \\
\hline $\begin{array}{l}\text { Nowinski et } \\
\text { al. }{ }^{7}\end{array}$ & $54, \mathrm{M}$ & $\begin{array}{l}\text { Right periorbital erythema } \\
\text { and edema (LEP + DLE) and } \\
\text { proptosis }\end{array}$ & $\begin{array}{l}\text { Hyperpigmented plaques on the right } \\
\text { cheek, alopecia, scalp nodules, SLE ( } 1 \\
\text { year later) }\end{array}$ & - & CLQ + topical steroid \\
\hline $\begin{array}{l}\text { Nowinski et } \\
\text { al. }{ }^{7}\end{array}$ & $33, F$ & $\begin{array}{l}\text { Left eyelid erythema and } \\
\text { edema (LEP + DLE) }\end{array}$ & $\begin{array}{l}\text { Hyperpigmented plaque on the right } \\
\text { eyebrow (LEP + DLE) }\end{array}$ & - & CLQ \\
\hline $\begin{array}{l}\text { Nowinski et } \\
\text { al. }{ }^{7}\end{array}$ & $37, F$ & $\begin{array}{l}\text { Left eyelid erythema an } \\
\text { edema }\end{array}$ & Loss of eyelashes, alopecia & - & CLQ+ topical steroid \\
\hline $\begin{array}{l}\text { Sheehan- } \\
\text { Dare et al. }{ }^{8}\end{array}$ & $47, \mathrm{M}$ & Right eyelid edema (LEP) & $\begin{array}{l}\text { Oedema of the right eyebrow, forehead } \\
\text { and cheek hyperpigmented plaque with } \\
\text { alopecia on the right preauricular area }\end{array}$ & $\begin{array}{l}\text { Polyclonal } \\
\text { gammaglobulinemia } \\
\text { ANA }(1: 500)\end{array}$ & $\begin{array}{l}\text { Oral prednisolone + } \\
\text { topical steroid }\end{array}$ \\
\hline $\begin{array}{l}\text { Magee et } \\
\text { al. }{ }^{9}\end{array}$ & $41, M$ & $\begin{array}{l}\text { Subcutaneous nodule on the } \\
\text { right cheek (LEP) }\end{array}$ & $\begin{array}{l}\text { Periorbital swelling on the right } \\
\text { side, proptosis, left submandibular, } \\
\text { preauricular, and temporal } \\
\text { subcutaneous nodules, alopecia areata }\end{array}$ & - & $\mathrm{HCQ}$ \\
\hline $\begin{array}{l}\text { Franke et } \\
\text { al. } .^{10}\end{array}$ & $64, \mathrm{M}$ & $\begin{array}{l}\text { Bilateral periorbital erythema } \\
\text { and edema (LEP) }\end{array}$ & $\begin{array}{l}\text { Erythematous atrophic plaque on the } \\
\text { right arm }\end{array}$ & ANA (1:160) & - \\
\hline $\begin{array}{l}\text { Inuzuka et } \\
\text { al. }{ }^{11}\end{array}$ & $71, F$ & $\begin{array}{l}\text { Erythematous plaques on } \\
\text { the eyelids }\end{array}$ & $\begin{array}{l}\text { Subcutaneous indurations or nodules } \\
\text { with or without overlying erythema } \\
\text { on the hands, thigh and leg (LEP), oral } \\
\text { ulcers, arthralgia, fever }\end{array}$ & $\begin{array}{l}\text { ANA (1:160) High } \\
\text { ESR Anemia }\end{array}$ & Oral prednisolone \\
\hline $\begin{array}{l}\text { Pérez-Pastor } \\
\text { et al. }{ }^{1}\end{array}$ & $63, M$ & $\begin{array}{l}\text { Right eyelid erythema and } \\
\text { edema (LEP) }\end{array}$ & $\begin{array}{l}\text { Parotiditis (LEP) xerostomia, } \\
\text { xeropthalmia, indurated and atrophic } \\
\text { plaque on the right mandibular area }\end{array}$ & ANA $(1: 80)$ & Oral corticosteroid \\
\hline $\begin{array}{l}\text { Minami-Hori } \\
\text { et al. }{ }^{6}\end{array}$ & $47, F$ & $\begin{array}{l}\text { Erythema and edema on the } \\
\text { right cheek (LEP) }\end{array}$ & $\begin{array}{l}\text { Bilateral PO erythema and edema (LEP), } \\
\text { erythematous plaques on the forehead } \\
\text { (DLE), rheumatoid arthritis, sclerodactyly }\end{array}$ & ANA $(1: 640)$ & $\begin{array}{l}\text { Oral tacrolimus + Oral } \\
\text { prednisolone }\end{array}$ \\
\hline Present case & $43, F$ & $\begin{array}{l}\text { Bilateral PO and unilateral } \\
\text { malar erythema and edema } \\
\text { (LEP) }\end{array}$ & - & - & $\begin{array}{l}\text { HCQ + Topical } \\
\text { pimecrolimus }\end{array}$ \\
\hline
\end{tabular}


the literature and conducted a review of all the cases reported from 1982 to 2018 using PubMed. Periorbital erythema and edema have been described in 9 patients thus far, ${ }^{1,6-11}$ and the initial symptoms, other findings, positive laboratory tests and treatments are outlined in the table (Table 1). According to our knowledge, our case is the first with isolated periorbital involvement. Few cases of the linear form of LEP have been reported in the literature and the majority of these cases were observed in childhood ${ }^{12-14}$. In other reported cases, other dermatological involvement areas, alopecia, arthritis, fever or oral ulcer except for periorbital skin, and abnormal laboratory results such as ANA positivity, elevated sedimentation and anemia, have been reported.

Regarding the histopathological examination, the findings of lobular panniculitis and hyaline necrosis of fat together with mucin deposition and basement membrane degeneration are important factors in making the diagnosis of LEP4. The main histopathologic differential diagnoses of lupus panniculitis are dermatomyositis panniculitis and subcutaneous panniculitis-like T-cell lymphoma (SPTCL). Histopathologic and immunohistochemical features for dermatomyositis panniculitis are also seen in lupus panniculitis, and therefore, the differential diagnosis between these two types of panniculitis requires clinicopathological correlation. SPTCL is a rare form of non-Hodgkin lymphoma, in which lymphoma cells infiltrate preferentially into subcutaneous adipose tissue. A characteristic finding in favour of the diagnosis of SPTCL is that there is no involvement of the epidermis and dermis ${ }^{15}$. It largely presents as multiple, painless, subcutaneous nodules on the extremities and trunk. SPTCL is characterized histologically by neoplastic lymphoid cells that mainly infiltrate the lobular areas of the subcutaneous tissue ${ }^{16}$. LEP may be seen as an isolated disease, combined with DLE, or before or concurrent with SLE ${ }^{12}$. While DLE and SLE are known to develop in approximately $50 \%$ to $70 \%$ of patients with LEP, it has been shown in one study that there were lower frequency relations for both DLE and SLE of $10 \%$ and $30 \%$, respectively ${ }^{17}$. A study about LEP showed that patients had a lower frequency of both DLE and SLE at the time of diagnosis ${ }^{18}$. In another study, it was mentioned that the time interval from the onset of LEP to the SLE diagnosis ranged from several weeks to 4 years ${ }^{2}$. Although our case cannot be associated with DLE or SLE, this does not mean that there will not be any progression in terms of these diseases. It is necessary to follow-up patients in case further skin and systemic findings occur.

There are no specific serologic findings in LEP, but it has been suggested that systemic involvement may be seen in patients with LEP and ANA ${ }^{19}$. In another study, ANA was shown to be positive in nearly half of the patients, but the titer was low, even in the SLE patients ${ }^{17}$. Another study showed that the ANA test was positive in $50 \%$ of the patients at the period of the LEP onset. However, the ANA test was positive in $85.71 \%$ of cases at the SLE activity phase ${ }^{2}$. No serology positivity was found in our case, although it is not essential for the LEP diagnosis.

The first choice treatment for LEP is antimalarial therapy, especially hydroxychloroquine at dosages of $200 \mathrm{mg}$ to $400 \mathrm{mg} /$ day in which produces a response in 6-8 weeks. Systemic corticosteroids are often useful for severe cases accompanied by SLE ${ }^{1,2}$. Minami-Hori et al. ${ }^{6}$ reported a case of periorbital LEP successfully treated with oral tacrolimus. Other systemic therapies can be considered as thalidomide, cyclosporine, intravenous immunoglobulins and rituximab². In addition, methotrexate, azathioprine, cyclophosphamide have been described as successful. Surgical debridement and resection of solitary lesions may be an option when other modalities are not successful20. Hydroxychloroquine was preferred in our case, which was the first-line treatment agent for LEP. A dosage of $200 \mathrm{mg} /$ day dosage was used for 6 months and significant improvement in the periorbital erythema and induration were observed after that period. Topical calcineurin inhibitors have a low risk of atrophy and telangiectasia development, and this is why they are generally preferred. Thus, in areas such as the face, the use of topical calcineurin inhibitors is an effective and safe choice. Our report is the first to report the use of topical pimecrolimus in addition to systemic hydroxychloroquine.

LEP is an uncommon form of DLE, which also manifests as periorbital erythema, and edema is seen rarely. It is necessary to exclude LEP in differential diagnosis for cases presenting as asymptomatic periorbital erythema and edema. In terms of the treatment choices for these patients, it is safe to use topical calcineurin inhibitors combined with first-line therapies.

\section{Ethics}

Informed Consent: Informed consent was obtained from the patient for publication of this case report.

Peer-review: Internally peer-reviewed.

\section{Authorship Contributions}

Surgical and Medical Practices: D.M., S.M., O.D., H.Ö., Concept: D.M., S.M., O.D., H.Ö., Design: D.M., S.M., Data Collection or Processing: D.M., S.M., O.D., H.Ö., Analysis or Interpretation: D.M., O.D., H.Ö., Literature Search: D.M., S.M., Writing: D.M., S.M.

Conflict of Interest: No conflict of interest was declared by the authors.

Financial Disclosure: The authors declared that this study has received no financial support.

\section{References}

1. Pérez-Pastor G, Valcuende F, Tomás G, Moreno M: Lupus erythematosus panniculitis presenting as palpebral edema and parotiditis. Actas Dermosifiliogr 2007;98:549-52.

2. Zhao YK, Wang $F$, Chen $W N$, et al: Lupus panniculitis as an initial manifestation of systemic lupus erythematosus: A case report. Medicine (Baltimore) 2016:95:e3429.

3. Irgang S: Lupus erythematosus profundus: report of an example with clinical resemblance to Darier-Roussy sarcoid. Arch Derm Syphilol 1940;42:97-108.

4. Arai S, Katsuoka K: Clinical entity of Lupus erythematosus panniculitis/lupus erythematosus profundus. Autoimmun Rev 2009;8:449-52.

5. Bacanli A, Uzun S, Ciftcioglu MA, Alpsoy E: A case of lupus erythematosus profundus with unusual manifestations. Lupus 2005;14:403-5.

6. Minami-Hori $M$, Komatsu $S$, Komura $K$, lizuka $H$, Ishida-Yamamoto $A$ : Periorbital lupus profundus successfully treated with oral tacrolimus plus low-dose prednisolone. J Dermatol 2015;42:222-3.

7. Nowinski T, Bernardino V, Naidoff M, Parrish R: Ocular involvement in lupus erythematosus profundus (panniculitis). Ophthalmology 1982;89:1149-54.

8. Sheehan-Dare RA, Cunliffe WJ: Severe periorbital oedema in association with lupus erythematosus profundus. Clin Exp Dermatol 1988;13:406-7.

9. Magee KL, Hymes SR, Rapini RP, Yeakley JW, Jordon RE: Lupus erythematosus profundus with periorbital swelling and proptosis. J Am Acad Dermatol 1991;24(2 Pt 1):288-90.

10. Franke W, Kuhn A, Megahed M, Krutmann J, Ruzicka T, Lehmann P: Periorbital edema as the initial symptom of lupus erythematosus profundus. Case report and discussion of the literature. Hautarzt 1999;50:889-92. 
11. Inuzuka M, Tomita K, Tokura $Y$, Takigawa M: Lupus erythematosus profundus with unusual skin manifestation: subcutaneous nodules coexisting with eyelid plaques. J Dermatol 2001;28:437-41.

12. Fernandes S, Santos S, Freitas I, Salgado M, Afonso A, Cardoso J: Linear lupus erythematosus profundus as an initial manifestation of systemic lupus erythematosus in a child. Pediatric Dermatol 2014;31:378-80.

13. Nagai $Y$, Ishikawa $O$, Hattori $T$, Ogawa $T$ : Linear lupus erythematosus profundus on the scalp following the lines of Blaschko. Eur J Dermatol 2003; 13:294-6

14. Lee $H E$, Ko JY, Lee CW: A case of lupus erythematosus panniculitis presenting as combined linear and lipoatrophic skin lesions. Int J Dermatol 2011;50:203-5.

15. Santos-Briz A, Calle A, Linos K, et al: Dermatomyositis panniculitis: a clinicopathological and immunohistochemical study of 18 cases. J Eur Acad Dermatol Venereol 2018;32:1352-9.
16. Bagheri F, Cervellione KL, Delgado B, et al: An illustrative case of subcutaneous panniculitis-like T-cell lymphoma. J Skin Cancer 2011;2011:824528.

17. Park HS, Choi JW, Kim B, Cho KH: Lupus erythematosus panniculitis: clinicopathological, immunophenotypic, and molecular studies. Am J Dermatopathol 2010;32:24-30.

18. Massone C, Kodama K, Salmhofer W, et al: Lupus erythematosus panniculitis (lupus profundus): Clinical, histopathological, and molecular analysis of nine cases. J Cutan Pathol 2005;32:396-404.

19. Guissa VR, Trudes G, Jesus AA, Aikawa NE, Romiti R, Silva CA: Lupus erythematosus panniculitis in children and adolescents. Acta Reumatol Port 2012;37:82-5.

20. Patel RM, Marfatia YS: Lupus panniculitis as an initial manifestation of systemic lupus erythematosus. Indian J Dermatol 2010;55:99-101. 